\title{
ANALISIS PERUBAHAN CADANGAN KARBON DI KAWASAN GUNUNG PADANG KOTA PADANG
}

\author{
Rina Sukesi ${ }^{1}$, Dedi Hermon ${ }^{2}$, Endah Purwaningsih ${ }^{2}$ \\ Program Studi Pendidikan Geografi, \\ Fakultas Ilmu Sosial, Universitas Negeri Padang \\ Email: rinasukesi@gmail.com
}

\begin{abstract}
Abstrak
Penelitian ini bertujuan untuk mengetahui (1) perubahan tutupan lahan di Kawasan Gunung Padang tahun 1996, 2006, dan 2016, (2) perubahan cadangan karbon akibat dari perubahan tutupan lahan di kawasan Gunung Padang, Kota Padang. Jenis penelitian ini adalah deskriptif kuantitatif. Perubahan tutupan lahan dianalisis dari citra Landsat TM 5 tahun 1996 dan tahun 2006, serta citra Landsat 8 OLI tahun 2016, menggunakan ENVI 4.5 dan ArcGis 10.1 dengan metode supervised classification. Nilai cadangan karbon diperoleh dari persamaan $\mathrm{C}=\mathrm{B} \times \% \mathrm{C}(0,47)$, melalui pendugaan biomassa pada tiap jenis kantong karbon menggunakan persamaan allometrik, yaitu $B=0,11 \rho D^{2,62}, B=\exp \{-$ $2,134+2,530 \times \ln (\mathrm{D})\}, \mathrm{B}=0,281 \mathrm{D}^{2,06}$, dan $\mathrm{B}=0,030 \mathrm{D}^{2,13}$, dimana $\mathrm{D}$ (diameter pohon setinggi dada, $\mathrm{cm}$ ) dan $\rho$ (massa jenis kayu). Teknik pengambilan sampel menggunakan metode stratified random sampling yang mengacu pada teknik plot pada masing-masing kelas tutupan lahan yang kemudian dikonversi pada luasan hektar.

Hasil analisis menunjukkan bahwa (1) tutupan lahan di Kawasan Gunung Padang Kota Padang pada tahun 1996 terdapat hutan seluas 744,23 Ha (92,6\%), kebun campuran seluas 39,44 Ha (4,9\%), semak seluas $17,92 \mathrm{Ha} \mathrm{(2,2 \% ),} \mathrm{dan} \mathrm{permukiman} \mathrm{seluas} \mathrm{2,35} \mathrm{Ha}$ (0,3\%). Tahun 2006 tutupan lahan hutan seluas 696,84 Ha (87\%), kebun campuran seluas 18,84 Ha (2\%), semak seluas 37,55 Ha (5\%), dan permukiman seluas 50,71 Ha (6\%). Tahun 2016 tutupan lahan hutan seluas 533,50 Ha (66\%), kebun campuran seluas 69,14 Ha (9\%), semak seluas 119,81 Ha (15\%), dan permukiman seluas 81,49 Ha (10\%). (2) cadangan karbon tahun 1996 adalah sejumlah 495.800,03 ton, Tahun 2006 sejumlah 458.165,73 ton, dan tahun 2016 sejumlah 369.223,00 ton. Selama 20 terakhir, akibat perubahan tutupan lahan cadangan karbon pada Kawasan Gunung Padang telah berkurang sebanyak $126.577,03$ ton.
\end{abstract}

Kata kunci: Cadangan karbon, tutupan lahan, biomassa

\begin{abstract}
This study aims to determine (1) changes in land cover in the Mount Padang Region in 1996, 2006 and 2016, (2) changes in carbon stocks as a result of changes in land cover in the Mount Padang Region of Padang City. The type of research is quantitative descriptive. Changes in land cover isanalyzed based on Landsat TM 5 of 1996 and 2006, as well as Landsat 8 OLI of 2016, using ENVI 4.5 and ArcGIS 10.1 and supervised classification method. Value of carbon stocks is obtained from the equation $C$ $=B \times \% C(0.47)$, by predicting biomass on each type of carbon pool using allometric equations, which $D^{2,62} \rho B=0.11, B=\exp \{-2.134+2.530 \times \ln (D)\}, B=0.281 D^{2,06}$, and $B=0.030 D^{2,13}$, where $D$ (diameter at breast height of trees, $\mathrm{cm}$ ) and $\rho$ (wood density). The sampling technique used is stratified random sampling method which refers to the technique of each plot on land cover classes which are then converted to thehectares area.
\end{abstract}

\footnotetext{
${ }^{1}$ Mahasiswa Program Studi Pendidikan Geografi untuk Wisuda September 2017

${ }^{2}$ Dosen Jurusan Geografi Fakultas Ilmu Sosial Universitas Negeri Padang
} 
The results of the analysis show that (1) the land cover in the Mount Padang Region of Padang City in 1996 has forest area of $744.23 \mathrm{Ha}$ (92.6\%), mixed garden area of $39.44 \mathrm{Ha}$ (4.9\%), shrubs of 17, $92 \mathrm{Ha}(2.2 \%)$, and the settlement area of $2.35 \mathrm{Ha}$ (0.3\%). 2006 forest cover an area of $696.84 \mathrm{Ha}(87 \%)$, mixed garden area of $18.84 \mathrm{Ha}$ (2\%), shrubs covering $37.55 \mathrm{Ha}(5 \%)$, and residential area of 50.71 ha (6\%). 2016 forest cover an area of $533.50 \mathrm{Ha}(66 \%)$, mixed garden covering an area of $69.14 \mathrm{Ha}(9 \%)$, shrubs covering $119.81 \mathrm{Ha}(15 \%)$, and residential area of $81.49 \mathrm{Ha}(10 \%)$. (2) the carbon stock in 1996 amounted to 495,800.03 tons, in 2006 a number of 458,165.73 tons, and in 2016 a number of 369,223.00 tons. Over the last 20 years, as a result of land cover changes in carbon stocks in Padang Mountain Region has been reduced as much as 126,577.03 tons.

\section{Keywords: Carbon stocks, land cover, biomass}

\section{PENDAHULUAN}

Kehidupan di bumi terdiri dari manusia, hewan, dan tumbuhan, serta benda-benda mati sebagai pendukung kehidupan makhluk hidup. Udara bersih yang menjadi salah satu kebutuhan pokok manusia, membuat kita sebagai manusia wajib untuk menjaga dan melestarikan tanaman hutan sebagai penyerap karbon dioksida $\left(\mathrm{CO}_{2}\right)$ dan penghasil oksigen $\left(\mathrm{O}_{2}\right)$.

Hutan merupakan sumber daya alam yang sangat penting dan bermanfaat bagi hidup dan kehidupan baik secara langsung maupun tidak langsung. Hutan alami menyimpan karbon (C) dengan jumlah tertinggi bila dibandingkan dengan sistem penggunaan lahan pertanian. Hutan primer dengan keragaman jenis pepohonan berumur panjang dan serasah yang banyak merupakan gudang penyimpan $\mathrm{C}$ tertinggi (Hairiah dan Rahayu, 2007). Apabila hutan diubah fungsinya menjadi lahan-lahan pertanian, perkebunan, ladang penggembalaan atau menjadi permukiman seperti yang terjadi di kota-kota besar maka jumlah $\mathrm{C}$ tersimpan akan merosot dan mengakibatkan terjadinya pemanasan global.
Kemajuan teknologi dan pertambahan penduduk yang banyak terjadi di kota, meningkatkan jumlah kendaraan bermotor dan kawasan industri di daerah perkotaan. Kota Padang merupakan ibukota Provinsi Sumatera Barat yang berfungsi sebagai pusat kegiatan perdagangan, jasa, pendidikan, pariwisata, transportasi, dan industri. Hermon (2009) juga telah menjelaskan bahwa pertambahan penduduk di Kota Padang secara umum selalu menunjukkan tren positif, dengan kata lain selalu meningkat setiap periode. Pertambahan penduduk dan pembangunan wilayah yang juga selalu dinamis dengan kecenderungan selalu meningkat setiap tahunnya mengakibatkan kebutuhan lahan terbangun terus bertambah. Umumnya perkembangan terjadi ke daerah pinggiran bagian timur, utara, dan selatan Kota Padang yang sebagian wilayah tersebut masih didominasi sebagai kawasan hutan dan areal pertanian masyarakat.Kawasan hutan yang dimiliki Kota Padang cukup luas pada bagian timur dan selatan kota, salah satunya adalah Kawasan perbukitan Gunung Padang atau lebih sering disebut dengan Gunung Siti Nurbaya 
yang terletak di Kecamatan Padang Selatan, Kota Padang.

Kawasan Gunung Padang ini menjadi salah satu wilayah hutan yang memiliki peran penting bagi kelestarian lingkungan di Kota Padang khususnya di Kecamatan Padang Selatan, mengingat hutan yang memiliki fungsi sebagai penyerap zat karbon dioksida $\left(\mathrm{CO}_{2}\right)$ dan menghasilkan oksigen. Kawasan Gunung Padang yang sebenarnya sangat berpotensi sebagai paru-paru kota (Griyawisata, 2010), dan juga telah direncanakan sebagai salah satu kawasan sabuk hijau (green belt) nya kota Padang sebagaimana yang tertera dalam RTRW (rencana tata ruang wilayah) tahun 2010-2030, sehingga pemerintah dapat mempertimbangkan perencanaan pembangunan di Kawasan Gunung Padang dengan mengetahui perubahan cadangan karbon sebagai akibat dari perubahan tutupan lahan pada kawasan Gunung Padang.

Penulis merasa begitu pentingnya untuk mengetahui cadangan karbon yang tersedia akibat dari perubahan tutupan lahan hutan Kawasan Gunung Padang, penelitian akan dilakukan dengan judul

"Analisis Perubahan Cadangan Karbon di Kawasan Gunung Padang Kota Padang”.

\section{METODE PENELITIAN}

Jenis penelitian yang dipakai adalah penelitian deskriptif kuantitatif. Sujarweni (2014), penelitian deskriptif adalah penelitian yang dilakukan untuk mengetahui nilai masing-masing variabel. Kuantitatif adalah jenis penelitian yang menghasilkan penemuanpenemuan yang dapat dicapai dengan menggunakan prosedur-prosedur statistik atau cara-cara lain dari kuantifikasi (pengukuran). Penelitian ini dilakukan untuk mengetahui nilai cadangan karbon pada masing-masing tutupan lahan pada kawasan Gunung Padang. Penghitungan cadangan karbon yang dilakukan adalah mengukur diameter pohon pada sampel dan nilai-nilai diameter tersebut dimasukkan kedalam persamaan allometrik biomassa yang akan menjadi acuan dalam menghitung cadangan karbon.

Teknik dalam pengumpulan data sekunder dengan melakukan interpretasi citra satelit Landsat 8 OLI tahun 2016, citra Landsat TM 5 tahun 2006, dan citra landsat TM 5 tahun 1996 kawasan Gunung Padang menggunakan softwareENVI 4.5 dan Arc GIS 10.1. Menggunakan metode supervised classification pada masing-masing citra dan diklasifikasikan menjadi empat kelas tutupan lahan, yaitu (1) hutan (2) kebun campuran (3) semak (4) permukiman. Selanjutnya data perubahan tutupan lahan dilakukan dengan mengoverlay peta tutupan lahan hasil klasifikasi pada masingmasing tahun.

Pendugaan cadangan karbon pada masing-masing tutupan lahan dilakukan dengan metode stratified random sampling (sampel acak berstrata). Menggunakan teknik plot dikembangkan oleh Hairiah dan Rahayu (2007) yang telah dimodifikasi ukuran plot oleh Hermon (2008) pada tiap tutupan lahan. Ukuran plot $10 \times 10 \mathrm{~m}$ untuk pengambilan sampel pohon, $2 \times 2$ untuk sampel tumbuhan bawah, dan $1 \times 1$ untuk sampel serasah. Sampel pohon diukur dengan metode non destructive sedangkan sampel serasah dan tumbuhan bawah dengan metode destructive. Nilai cadangan karbon diperoleh dari persamaan $\mathrm{C}=\mathrm{B} \times \% \mathrm{C}$ 
$(0,47)$, melalui pendugaan biomassa pada tiap jenis kantong karbon menggunakan persamaan allometrik, yaitu $\mathrm{B}=0,11 \quad \rho \quad \mathrm{D}^{2,62}, \mathrm{~B}=\exp \{-$ $2,134+2,530 \times \ln (\mathrm{D})\}, \quad \mathrm{B}=0,281$ $\mathrm{D}^{2,06}$, dan $\mathrm{B}=0,030 \mathrm{D}^{2,13}$, dimana $\mathrm{D}$ (diameter pohon setinggi dada, $\mathrm{cm}$ ) dan $\rho$ (massa jenis kayu). Pendugaan cadangan karbon pada tahun 1996 dan tahun 2006 berdasarkan perhitungan cadangan karbon tahun 2016 yang dikonversi dengan luasan masing-masing tutupan lahan.

\section{HASIL PENELITIAN}

\section{Perubahan Tutupan Lahan}

Hasil analisis citra satelit Landsat TM 5 tahun 1996, citra Landsat TM 5 tahun 2006, dan citra Landsat 8 OLI tahun 2016 dengan menggunakan ENVI 4.5 dan Arc Gis 10.1 diperoleh data perubahan tutupan lahan selama rentang waktu 20 tahun terakhir yakni tahun 19962006 dan tahun 2006-2016. Luas masing-masing tutupan lahan pada tahun 1996, 2006, dan 2016 adalah sebagai berikut:

Tabel 1. Luas tutupan lahan Kawasan Gunung Padang tahun1996, 2006, dan

\begin{tabular}{|l|r|r|r|}
\hline \multirow{4}{*}{ Tutupan Lahan } & \multicolumn{3}{|c|}{$\begin{array}{c}\text { Luas Tutupan Lahan } \\
\text { (Ha) }\end{array}$} \\
\cline { 2 - 4 } & $\mathbf{1 9 9 6}$ & $\mathbf{2 0 0 6}$ & $\mathbf{2 0 1 6}$ \\
\hline Hutan & 744,23 & 696,84 & 533,50 \\
\hline Kebun Campuran & 39,44 & 18,84 & 69,14 \\
\hline Semak & 17,92 & 37,55 & 119,81 \\
\hline Permukiman & 2,35 & 50,71 & 81,49 \\
\hline Jumlah & $\mathbf{8 0 3 , 9 4}$ & $\mathbf{8 0 3 , 9 4}$ & $\mathbf{8 0 3 , 9 4}$ \\
\hline \multicolumn{4}{|c}{$\mathbf{2 0 0 6}$}
\end{tabular}

Sumber: Analisis tutupan lahan ENVI 4.5 dan ArcGis 10.1

Perubahan luas tutupan lahan pada kawasan Gunung Padang diantaranya adalah pada tutupan lahan hutannya. Kawasan hutan Gunung Padang pada tahun 1996 seluas 744,23 Ha dan pada tahun 2006 menurun sejumlah 47,39 Ha menjadi 696,84 $\mathrm{Ha}$, dan terus mengalami penurunan luas kawasan hutan sejumlah 163,34 Ha hingga hanya tersisa seluas $533,50 \mathrm{Ha}$ pada tahun 2016.

Perubahan luas juga terjadi pada tutupan lahan kebun campuran. Tahun 1996 tutupan lahan kebun campuran pada kawasan Gunung Padang seluas 39,44 Ha. Mengalami penurunan luas sejumlah 20,60 $\mathrm{Ha}$ pada tahun 2006 hingga tersisa 18,84 $\mathrm{Ha}$, dan mengalami penambahan kembali pada tahun 2016 sejumlah 50,3 Ha menjadi 69,14 Ha.

Semak yang terdapat pada kawasan Gunung Padang pada tahun 1996 seluas 17,92 Ha, mengalami penambahan 19,63 Ha pada tahun 2006 dan menjadi 37,55 Ha. Tahun 2016 bertambah seluas 82,26 Ha dari luas semak tahun 2006 hingga luasnya mencapai 119,81 Ha.

Sedangkan perubahan tutupan lahan pada periode 1996-2006 dan periode 2006-2016 adalah sebagai berikut : 


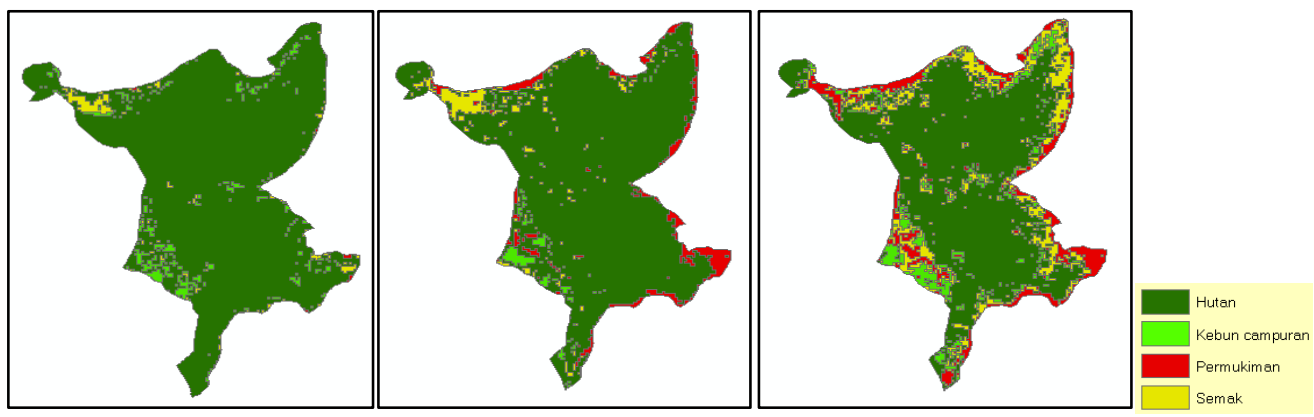

Gambar 1. Perubahan tutupan lahan tahun 1996, 2006, dan 2016

Luas tutupan lahan permukiman kawasan Gunung Padang terus mengalami penambahan luasnya. Tahun 1996 area permukiman di kawasan Gunung Padang 2,35 Ha, dan pada tahun 2006 bertambah seluas 48,36 Ha dari luas area permukiman tahun 1996 menjadi 50,71 Ha. Bertambah kembali seluas $30,78 \mathrm{Ha}$ dari luas area permukiman tahun 2006 dan total luas area permukiman hingga tahun 2016 adalah seluas 81,49 Ha.

Tabel 2. Perubahan tutupan lahan Kawasan Gunung Padang tahun 1996-2006 dan 2006-2016

\begin{tabular}{|c|c|c|c|}
\hline \multirow[b]{2}{*}{$\begin{array}{c}\text { Perubahan } \\
\text { Tutupan Lahan }\end{array}$} & \multicolumn{2}{|c|}{ Luas (Ha) } & \multirow[b]{2}{*}{$\begin{array}{l}\text { Total } \\
\text { (Ha) }\end{array}$} \\
\hline & $\begin{array}{c}\text { Th } \\
1996- \\
2006 \\
\end{array}$ & $\begin{array}{c}\text { Th } \\
2006- \\
2016 \\
\end{array}$ & \\
\hline $\begin{array}{lr}\text { Hutan } & \text { berubah } \\
\text { menjadi } & \text { Kebun } \\
\text { campuran } & \\
\end{array}$ & 13,65 & 51,53 & 65,18 \\
\hline $\begin{array}{l}\text { Hutan berubah } \\
\text { menjadi semak }\end{array}$ & 23,73 & 101,28 & 125,01 \\
\hline $\begin{array}{l}\text { Hutan berubah } \\
\text { menjadi } \\
\text { permukiman }\end{array}$ & 38,10 & 22,05 & 60,15 \\
\hline $\begin{array}{l}\text { Kebun campuran } \\
\text { berubah menjadi } \\
\text { hutan }\end{array}$ & 25,92 & 3,81 & 29,73 \\
\hline $\begin{array}{l}\text { Kebun campuran } \\
\text { berubah menjadi } \\
\text { permukiman }\end{array}$ & 2,76 & 0,62 & 3,38 \\
\hline $\begin{array}{l}\text { Kebun campuran } \\
\text { berubah menjadi } \\
\text { semak }\end{array}$ & 5,60 & 3,10 & 8,70 \\
\hline $\begin{array}{l}\text { Permukiman } \\
\text { berubah menjadi } \\
\text { hutan }\end{array}$ & 0,06 & 0,31 & 0,37 \\
\hline $\begin{array}{l}\text { Permukiman } \\
\text { berubah menjadi }\end{array}$ & & 0,26 & 0,26 \\
\hline
\end{tabular}

\begin{tabular}{|c|c|c|c|}
\hline \multirow[b]{2}{*}{$\begin{array}{c}\text { Perubahan } \\
\text { Tutupan Lahan }\end{array}$} & \multicolumn{2}{|c|}{ Luas (Ha) } & \multirow[b]{2}{*}{$\begin{array}{l}\text { Total } \\
\text { (Ha) }\end{array}$} \\
\hline & $\begin{array}{c}\text { Th } \\
1996- \\
2006 \\
\end{array}$ & $\begin{array}{c}\text { Th } \\
2006- \\
2016 \\
\end{array}$ & \\
\hline \multicolumn{4}{|l|}{ kebun campuran } \\
\hline $\begin{array}{l}\text { Permukiman } \\
\text { berubah menjadi } \\
\text { semak }\end{array}$ & & 1,56 & 1,56 \\
\hline $\begin{array}{l}\text { Semak berubah } \\
\text { menjadi hutan }\end{array}$ & 2,11 & 7,40 & 9,51 \\
\hline $\begin{array}{lr}\text { Semak } & \text { berubah } \\
\text { menjadi } & \text { kebun } \\
\text { campuran } & \\
\end{array}$ & 0,03 & 6,04 & 6,07 \\
\hline $\begin{array}{l}\text { Semak berubah } \\
\text { menjadi } \\
\text { permukiman }\end{array}$ & 7,56 & 10,24 & 17,80 \\
\hline
\end{tabular}

Sumber : analisis perubahan tutupan lahan dengan ArcGis 10.1

Selama 20 tahun terakhir kawasan hutan sebagai penyimpan cadangan karbon tertinggi telah berkurang seluas $65,18 \mathrm{Ha}$ menjadi kebun campuran. Kawasan hutan yang berubah menjadi semak seluas 125,01 Ha, dan yang berubah menjadi kawasan permukiman seluas 60,15 Ha.

Kawasan hutan yang berubah menjadi tutupan lahan lain yang masih dapat menyimpan sedikit cadangan karbon dalam kurun waktu 20 tahun antara tahun 1996 hingga tahun 2016 seluas 190,19 $\mathrm{Ha}$, dan kawasan yang benar-benar telah kehilangan atau tidak dapat menyerap karbon lagi adalah seluas 60,15 Ha, dan jika dijumlahkan seluruh luas tutupan lahan hutan yang berubah menjadi tutupan lahan lain selama 
rentang waktu 20 tahun terakhir adalah sebanyak 250,34 Ha.

Perubahan tutupan lahan terjadi pada tiap tutupan lahan yang ada di Kawasan Gunung Padang. Perubahan yang terjadi tidak hanya pada tutupan lahan hutan sebagai penyimpan cadangan karbon tetapi juga terjadi pada tutupan lahan lainnya, seperti kebun campuran dan semak yang masih dapat menyerap karbon meskipun kemampuannya lebih kecil dari tutupan lahan hutan, juga terjadi pada tutupan lahan permukiman yang tidak dapat menyerap karbon lagi.

Perubahan yang terjadi pada tutupan lahan kebun campuran dan semak mengalami dinamika atau naik turun dalam perubahannya, tidak seperti tutupan lahan hutan yang konsisten ke arah negatif atau seperti permukiman yang selalu bertambah. Kebun campuran yang berubah menjadi tutupan lahan lain selama rentang waktu 20 tahun terakhir adalah seluas 41,81 Ha. Tutupan lahan semak yang berubah menjadi tutupan lahan lain selama rentang waktu 20 tahun terakhir adalah sebanyak 33,38 Ha.

\section{Perubahan Cadangan Karbon}

Perubahan cadangan karbon pada masing-masing tutupan lahan adalah sebagai berikut.

Tabel 3. Cadangan Karbon masing-masing tutupan lahan tahun 1996,2006, dan

\begin{tabular}{|c|r|r|r|r|r|r|}
\hline \multirow{2}{*}{ Tahun } & \multicolumn{3}{|c|}{ Luas Kawasan (Ha) } & \multicolumn{2}{c|}{ Cadangan Karbon (ton) } \\
\cline { 2 - 7 } & Hutan & $\begin{array}{c}\text { Kebun } \\
\text { Campuran }\end{array}$ & Semak & Hutan & $\begin{array}{c}\text { Kebun } \\
\text { Campuran }\end{array}$ & Semak \\
\hline $\mathbf{1 9 9 6}$ & 744,23 & 39,44 & 17,92 & $482.581,06$ & $13.196,23$ & 22,74 \\
\hline $\mathbf{2 0 0 6}$ & 696,84 & 18,84 & 37,55 & $451.851,96$ & $6.303,67$ & 10,10 \\
\hline $\mathbf{2 0 1 6}$ & 533,50 & \multicolumn{6}{|c|}{69,14} & 119,81 & $345.937,41$ & $23.133,55$ & 152,04 \\
\hline \multicolumn{7}{|c|}{ Sumber: analisis cadangan karbon berdasarkan kelas tutupan lahan } \\
\hline
\end{tabular}

Perubahan cadangan karbon pada kawasan hutan Gunung Padang pada beberapa tahun terakhir. Rentang 10 tahun antara tahun 1996 hingga tahun 2006, luas tutupan lahan hutan berkurang sebanyak 47,39 $\mathrm{Ha}$, yang sebelumnya seluas $744,23 \mathrm{Ha}$ menjadi 696,84 Ha dan diiringi dengan perubahan cadangan karbon pada kawasannya yakni berkurang sekitar 30.729,10 ton, dari 482.581,06 ton menjadi $451.851,96$ ton. 10 tahun selanjutnya dari tahun 2006 hingga tahun 2016 tutupan lahan hutan berkurang seluas 163,34 $\mathrm{Ha}$ dan cadangan karbon pada kawasan tutupan lahan hutanpun juga berkurang sebanyak 105.914,55 ton menjadi 345.937,41 ton.

Cadangan karbon pada kawasan kebun campuran mengalami dinamika dalam kurun waktu 20 tahun terakhir. Kawasan Gunung Padang juga memiliki kawasan tutupan lahan kebun campuran pada tahun 1996 memiliki luas 39,44 Ha dengan cadangan karbon sebanyak 13.196,23 ton. Tahun 2006 kebun campuran memiliki luas 18,84 Ha dengan cadangan karbon sebanyak 6.303,67 ton, sehingga terlihat adanya perubahan antara tahun 1996 dan tahun 2006, baik dari luas kawasan tutupan lahannya maupun cadangan karbonnya. Selanjutnya tahun 2016 kawasan tutupan lahan kebun campuran ini memiliki luas 69,14 Ha dengan cadangan karbon sebanyak 23.133,55 ton.

Tutupan lahan semak juga mengalami perubahan cadangan karbon, yakni pada tahun 1996 
mampu menyimpan cadangan karbon sebanyak 22,74 ton, 10 tahun selanjutnya menurun menjadi 10,10 ton, dan pada tahun 2016 meningkat kembali menjadi 152,04 ton, namun peningkatan cadangan karbon pada tutupan lahan semak ini meskipun mengalami peningkatan mengindikasikan bahwa tutupan lahan semak telah bertambah yang berarti hal ini menandakan berkurangnya tutupan lahan lain sebagai penyimpan cadangan karbon yang lebih besar seperti kebun campuran atau bahkan tutupan lahan hutan.

Tahun 1996 hutan kawasan Gunung Padang memiliki luas 744,23 $\mathrm{Ha}$, dengan kebun campuran seluas 39,44 Ha, dan semak seluas 17,92 Ha dapat menyimpan cadangan karbon sejumlah 495.800,03 ton. Tahun selanjutnya yakni tahun 2006 luas tutupan hutan sekitar 696,84 Ha, dengan kebun campuran seluas 18,84 Ha, dan semak seluas $37,55 \mathrm{Ha}$ dapat menyimpan cadangan karbon sebanyak 458.165,73 ton, sedangkan pada tahun 2016 luas kawasan hutan berkurang menjadi 533,50 Ha, dengan kebun campuran seluas 69,14 Ha, dan semak seluas 119,81 Ha mampu menyimpan cadangan karbon sebanyak 369.223,00 ton.

\section{PENUTUP}

\section{a. Kesimpulan}

Berdasarkan hasil analisis citra landsat TM 5 dan 8 OLI pada tahun 1996, 2006, dan 2016 dengan menggunakan ENVI 4.5 maka diperoleh kesimpulan bahwa perubahan tutupan lahan pada kawasan Gunung Padang terjadi dalam rentang waktu 20 tahun terakhir, pada tahun 1996 - 2006 dan antara tahun 2006 - 2016. Sebanyak 74,71 Ha pada tahun 1996-2006 dan sebanyak 174,17 Ha pada tahun 20062016 tutupan lahan hutan di kawasan Gunung Padang berubah menjadi tutupan lahan lain baik itu yang berubah menjadi kebun campuran dan semak yang masih mampu menyerap karbon dengan jumlah yang lebih kecil dari kemampuan kawasan hutan ataupun berubah menjadi area permukiman yang tidak dapat lagi menyerap karbon.

Berdasarkan perubahan tutupan lahan yang terjadi di kawasan Gunung Padang dalam rentang waktu 20 tahun terakhir dapat disimpulkan bahwa pada tahun 1996-2006 kawasan Gunung Padang telah kehilangan cadangan karbon sebanyak $37.634,30$ ton, 10 tahun selanjutnya pada tahun 2006-2016 kawasan Gunung Padang kehilangan kembali cadangan karbonnya sebanyak 88.942,73 ton. Selama rentang 20 tahun terakhir akibat perubahan tutupan lahan, kawasan Gunung Padang cadangan karbonnya telah berkurang sebanyak $126.577,03$ ton.

\section{b. Saran}

dan pembahasan maka dapat disarankan mengenai beberapa hal sebagai berikut:

1. Pemerintah harus mencegah adanya penambahan lahan untuk permukiman dengan tidak memberlakukan IMB (izin mendirikan bangunan) di Kawasan Gunung Padang.

2. Pemerintah harus melakukan program reboisasi pada tutupan lahan semak untuk mencegah terjadinya bencana longsor.

3. Pemerintah menanami kebun campuran dengan tanaman yang memiliki manfaat bagi masyarakat namun juga memiliki kemampuan 
menyerap karbon tinggi seperti tanaman durian.

Pemerintah harus berupaya untuk terus mensosialisasikan akan pentingnya menjaga kelestarian kawasan hutan dan juga menggalakkan program menanam pohon.

\section{DAFTAR PUSTAKA}

Hermon , Dedi 2014. Geografi Bencana Alam. Rajawali Press. Jakarta 